\title{
A Note on Vanadium Mineralisation in Daba Gamlin Area, West Siang District, Arunachal Pradesh - P. S. Misra ${ }^{*}$, A. Kumar ${ }^{2}$, A. K. Singh ${ }^{3}$, Geological Survey of India. ${ }^{1}$ Lucknow, ${ }^{2}$ Chandigarh, ${ }^{3}$ Patna. (*E: psm28gsi@ rediffmail.com)
}

An investigation for limestone was undertaken by Geological Survey of India, in Daba Gamlin area, West Siang district, Arunachal Pradesh (toposheet no. 82L/12). The area lies in the Lesser Himalayan region. The metasediments comprising sericite-quartz phyllite, garnetiferous phyllite and schist, graphite schist, carbonaceous phyllite, quartzite, carbonates, and chert constitute the Khetabari Formation of Palaeoproterozoic Bomdila Group.

Carbonaceous phyllite is exposed near Daba Gamlin and extends in the south westerly direction. It is dark grey to black in colour, very fine grained and soils the finger. Two foliation planes can be inferred. It has thin graphitic bands (1-5mm). Graphite is of amorphous nature. It is also observed as thin flakes admixed with micaceous minerals. At places carbonaceous phyllite has very thin silica veins and occasional ferruginous patches having small pyrite grains and oxidised cavities. The carbonate bands are within the carbonaceous phyllite and at places it is also in contact with mica schist.

Dolomitic crystalline limestone is exposed in Daba Gamlin Liromoba sector, to the southwest of Daba Gamlin. The physical character of the rock indicates that it is a hard, compact, fine-medium grained, bluish grey limestone having banded character with elephant skin weathering pattern on the surface, hence characterised as dolomitic limestone. The $\mathrm{MgO}$ content varies from $1 \%$ to $15 \%$. The rock specimen when stained with Alizarin Red does not stain the maximum part of the rock. The dolomitic limestone is coarse and crystalline at places, with grain size of the crystals ranging from 2$5 \mathrm{~mm}$ and concentrated as $1-2 \mathrm{~cm}$ bands having translucent calcite grains. The limestone is siliceous and composed of interlocking crystalline grains of the constituent minerals viz. calcite/ dolomite and of phaneritic texture, thus representing a recrystallised limestone. Thin silica/quartz- calcite veins and veinlets $(1-2 \mathrm{~mm})$ are intruding the dolomitic limestone and are parallel as well as oblique to the banding. The limestone occurs as lenses within carbonaceous phyllite and associated graphitic schist. It is fine grained, carbonaceous in the lower part, while the upper part is siliceous and crystalline. Specks of pyrite and chalcopyrite occur occasionally. During the investigation, five different bands/lenses of dolomitic limestone were delineated.
The discontinuous bands of dolomitic limestone, striking NE-SW have variable outcrop width of $8-50 \mathrm{~m}$ and limited strike lengths of 100$300 \mathrm{~m}$. The width is more in the central part as compared to the ends. Joint filled carbonaceous partings (up to $10 \mathrm{~cm}$ ) are evident within the dolomitic limestone. Three carbonate caves were observed, to the southwest of Daba Gamlin. During the investigation vanadium mineralization was reported in carbonaceous phyllite and dolomitic limestone of Daba Gamlin area. Vanadium values in the samples range from 323-1971 ppm.

Vanadium is a trace element that is widely distributed in nature. The average abundance of vanadium is $135 \mathrm{ppm}$ (Clarke's value). Vanadium is also closely associated with organic-rich sediments. Vanadium is extracted from several different types of mineral deposits and from fossil fuels. These deposits include vanadiferous titanomagnetite (VTM) deposits, sandstone-hosted vanadium (with or without uranium) deposits (SSV deposits), and vanadium-rich black shales (USGS, 2017). Vanadium-rich black shales occur in marine successions that were deposited in epeiric (inland) seas and on continental margins. Vanadium (V) is a critical metal that is used principally in the production of metal alloys, such as high-strength steel and alloys for use in the aerospace industry. Secondary uses are as a catalyst in the chemical industry, and in ceramics, glasses, and pigments. Vanadium is becoming more widely used in green technology applications, especially in battery technology. In India, Vanadiferous titanomagnetite (VTM) deposits occur in Mayurbhanj-Singhbhum area.

According to the United States Geological Survey (USGS), China, South Africa and Russia are the world's main producers of vanadium. Petroleum residue is another source of vanadium. Japan and the United States are understood to be the only countries to recover significant quantities of vanadium from this source. China dominates the world vanadium resources with $42 \%$ followed by Russia at $23 \%$, and Australia at $18 \%$.

The occurrence of Vanadium in carbonaceous phyllite / graphite schist from Daba Gamlin area, has opened a new vista for assessment of vanadium resources in Arunachal Pradesh. 